\title{
Norma Pecora, Enyonam Osei-Hwere \& Ulla Carlsson (Eds.): African media, African children. Gothenburg: The International Clearinghouse on Children, Youth and Media, NORDICOM. 2008
}

\section{Teke Ngomba}

MedieKultur 2010, 48, 167-170

Published by SMID | Society of Media researchers In Denmark | www.smid.dk The online version of this text can be found open access at www.mediekultur.dk

Beyond the plethora of African and global declarations on the rights of the child, if there is any one book that recently captures the theme of African children as "people with a voice too" and jettisons in its course the notion that African children "should be seen not heard", then it is African Media, African Children.

With a foreword by Ulla Carlsson and an introduction by Firdoze Bulbulia, the book focuses on "Article 13" of the Convention on the Rights of the Child', seeking to discuss different processes, practices and challenges of implementing this in Africa, as well as broader issues of academic interest regarding children, youth and the media in Africa.

Generally speaking, the seventeen chapters that make up the book (though not arranged as such in the book) could well be divided into six main thematic sections:

a. a general outline about "Article 13" in Africa and broader issues concerning African children, youth and media (chapter 1 ),

b. media policies and programming for children and youths in Africa (chapters 3, 9, $13,14,15,16)$,

c. the production of children's/youth's programmes by children/youths themselves (chapters 8, 10, 17),

d. analyses of the contents of children's programmes and the reception of these programmes by children (chapters $4,5,6$ ), 
e. African children and information and communication technologies (chapters 7, 11) and lastly,

$\mathrm{f}$. outlines of the way forward regarding research on children, youth and the media in Africa (chapters 2, 12).

In the first chapter, Osei-Hwere and Pecora decry the paucity of academic research on children, youth and media in Africa and note that the series of constraints forestalling the institutionalisation of children's media in Africa have made children's media in the continent to be very often "a luxury" (p. 17).

Six of the seventeen chapters of the book (chapters $3,9,13,14,15$ and 16) could be said to focus on media policies and programming for children and youths across Africa.

As concerns media policies, in chapter nine, Akrofi-Quarcoo critically examines policies on media education for children and youths in Ghana arguing that, in Ghana, the concept of media education "appears a 'stranger' even to drafters of the country's educational curricula" (p. 139) and generally speaking, there is "relatively little progress" to encourage media education in Chana (p. 145).

Evusa, in chapter fifteen, examines another issue of media policy regulations concerning the content of children's television programmes in Kenya and concludes that there is "overwhelming evidence of a lack of comprehensive policy regulating the broadcasting and telecommunication industry" (p. 207) and, as a result of this, children are easily exposed to "indecent material".

As concerns the provision of children's programmes in Africa, Patrick Osei-Hwere, in chapter 13, examines the challenges of local production of television programmes for children in Ghana, indicating that compared to other African countries, the percentage of time "allotted to children's programmes in Ghana is commendable" (p. 191). Possible improvements of the situation however are mitigated by the limitations in human and financial resources. These same issues and similar conclusions feature in discussions of the South African case by Owen (chapter 3) and Boateng (chapter 14) and in the Zambian case by Kapatamoyo (chapter 16).

In chapter 8, Brazeau examines initiatives of "youth media" in West Africa, which were supported by the international NGO Plan. Brazeau shows how these different initiatives, some like Radio Gune Yi in Senegal, whose programmes were recorded in front of a community, allowed children to "express themselves", raise awareness of the rights of the child and permitted the children to become "actors influencing the development of their communities" (p. 120).

These same themes resonate both in the tenth chapter by Goodman, Renard and Mendoza, who examine community youth video in South Africa as a tool for building democratic dialogue, as well as in the seventeenth chapter by Kaswoswe, who examines two youth media initiatives, Zimbabwe-Studio 263 and Handspeak, concluding that these initiatives are informing, instructing and empowering the youth in Zimbabwe (p. 231).

Howard (chapter 4), Boshoff and Prinsloo (chapter 5), and Workalemahu (chapter 6) address issues regarding the content and reception of children's programmes in Africa. While 
Boshoff and Prinsloo show in a gendered analysis of the content of children's entertainment programming in South Africa that generally male characters are in the majority and tend to be leaders of groups, thus reflecting in some ways the "off-screen" patriarchal society of South Africa, Howard and Workalemahu in discussions that touch on the reception of programmes demonstrate that African children are not passive consumers of media content. As Workalemahu indicates in a study of Ethiopian children's reception of Disney programmes, the children do not "passively adhere" to the values in the Disney films but are rather "critical, reflective of what they see, be it of content or standards of production" (p. 94).

Two chapters of African Media, African Children focus on ICTs and children in Africa. In chapter 7, Prinsloo and Walton critically examine strategies to bridge the digital divide in Africa by focusing on children's encounters with the Internet in the Western Cape in South Africa, where a "well funded programme has been rolled out to put computers and connectivity into otherwise poor and under resourced schools across the region" (p. 104).

By showing how the children, contrary to the expectations of the coordinators of the programme, made their own "situated meanings" of the software in particular, Prinsloo and Walton once more contributed to the long-held conclusion that bridging the digital divide goes beyond "physical access to computers and the Internet" (p. 101) and warrants far more creative and contextually sensitive approaches.

In the other chapter that looks at African children's encounters with ICTs, El Baghdady (chapter 11) examined Egyptian children's experience with Facebook and found that the "more time children invested on Facebook, the more socially active they appear to become" (p. 169). According to El Baghdady, most of the children interviewed in the study indicated that "digital practices through Facebook positively affect their offline socialization processes" as well as "helping them becoming more knowledgeable, social and able to deal with people from different nationalities" (p. 170).

Such findings both challenge commonly cited claims that spending a lot of time online might lead to offline "de-socialisation" and also open up avenues of further research on these and related issues in Africa. It is this last issue, options and challenges of research on media, youth and children in Africa, which is addressed by Nyamnjoh (chapter 2) and Nnoma-Addison (chapter 12).

In critiquing the neo-liberal ideology so characteristic of global media industries, Nyamnjoh, for instance, outlines close to three pages of possible research questions that, if handled with some methodological rigor and sensitivity, could "meaningfully challenge simplistic assumptions about children, media and globalization in Africa" (p. 32) and open up frontiers to achieving what Nnoma-Addison calls a "meaningful media-child relationship in Africa" (p. 178).

African Media, African Children is undoubtedly a rich collection, one which is without doubt welcome, especially in a continent where updated academic research on several issues of the media (especially about media and children) is wanting in scope and depth. While the editors should be praised for bringing together a collection of essays that use a 
range of methodological and theoretical approaches to cover all the key issues concerning children, media and youth in Africa, some "sideline issues" are worth pointing out.

In the quest to bring together all key issues in this area in one volume, there is no unifying perspective - theoretically or otherwise - tying the different (unnumbered!) chapters of the book together. As a result, each chapter often reads like an isolated section, without any clear connection to other parts of the book. This absence of a central "connecting" chord in the book is also evident in chapter 4 by Howard, where the three different issues examined in his chapter are not tied to the introduction or the conclusion.

Also, in addition to the fact that some chapters, e.g., chapters 3 and 14, all addressing a similar issue (broadcast programme provision for children in South Africa), could simply be fused into one chapter, there are some oversights like the absence of detailed methodological discussions in some chapters, especially in Workalemahu's discussion of Ethiopian children's reception of Disney in chapter 6.

Furthermore, though the book covers in detail about fifteen countries in Africa, more comparative cross-national studies on some of the key themes of interest (five of the seventeen chapters focus on one country, i.e., South Africa), as well as more detailed consideration of the print media, would have further strengthened the analytical value of African Media, African Children. But these are obviously issues to be considered in future scholarship.

Overall, the above minor issues do not substantially jeopardise the worth of African Media, African Children as a book that will inform policy, practice and research on media, children and youths within and out of the continent. It is a book that, overall, captures how African children, beyond being the face of the continent's human suffering, are upholding their "Article 13" rights by acting out their roles as "producers, creators as well as an audience" (Osei-Hwere \& Pecora, p. 15).

\section{Notes}

1. This famous "Article 13" states that: "1. The child shall have the right to freedom of expression; this right shall include freedom to seek, receive and impart information and ideas of all kinds, regardless of frontiers, either orally, in writing or in print, in the form of art, or through any other media of the child's choice. 2. The exercise of this right may be subject to certain restrictions, but these shall only be such as are provided by law and are necessary: (a) For respect of the rights or reputations of others; or (b) For the protection of national security or of public order (ordre public), or of public health or morals." (see UNICEF, 2009, The State of the World's Children: Special Edition 'Celebrating 20 Years of the Convention on the Rights of the Child', United Nations Children's Fund, New York, p. 76).

Teke Ngomba

Ph.D. Student

Institute of Information and Media Studies

Aarhus University, Denmark imvjnt@hum.au.dk 